\title{
Christian anthropology and the National Development Plan: The role of personhood
}

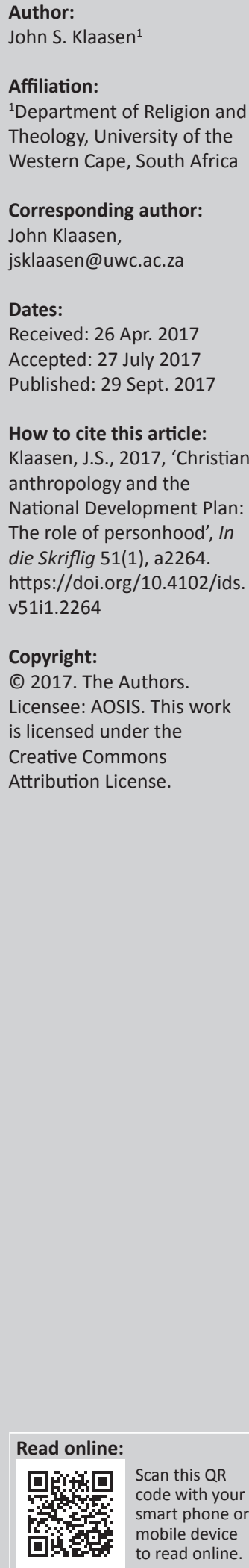

\begin{abstract}
This article is an attempt to analyse and assess the use of personal responsibility in the National Development Plan (NDP). Some signposts that Christian anthropology can make to the enhancement of the plan will then be suggested. An overview of the development debate will include the development debate after the two world wars, the church and state attempts for social transformation and the contributions of Korten and Sen who represent the peoplecentred and capability approaches. It will be followed by a Christian anthropology that is characterised by personhood and personal responsibility. The fact that constructive and sustainable development is embedded in personal integrity and responsibility will be argued.

The NDP acknowledged the shortcomings of the previous attempts by both state and church, and the global development debate. Instead of exclusive economic development, human capital and human capabilities are integral to development. Christian anthropology embeds responsibility within personhood and the two form part of an integral whole.
\end{abstract}

\section{Introduction}

This article is an attempt to engage critically with the NDP and to suggest some signposts that Christian anthropology can make to the enhancement of the plan. Firstly, a brief overview of the development debate will be presented. This overview will include the development debate after the two world wars, the church and state attempts for social transformation, and the contributions of Korten and Sen who represent the people-centred and capability approaches. Secondly, a Christian anthropology, characterised by personhood, will be outlined. Finally, personal responsibility for development as fundamental for development in the South African context will be proposed.

The contribution of this article will be the neglect of personal responsibility that is embedded in personhood. The fact that constructive and sustainable development is embedded in personal integrity and responsibility will be argued. The dominant development theories and activities have largely ignored personal responsibility which is embedded in personhood. Separate development, The Reconstruction and Development Plan (RDP), Sustainable Development and social welfare by Non-Governmental Organisations and Faith Based Organisations, including the church, failed to address the personal integrity and personal responsibility that persons must take for their own development. The NDP, draws from the different development initiatives and through a broad consultation process, sets out to present a vision for a developed South African nation by 2030. The interest of this article is to evaluate whether the plan considers the role of personal responsibility for development and to present some contours and markers for constructive and sustainable development which is found in Christian anthropology.

\section{Development in the South African context}

The concept development has received mixed reactions within both theological and secular debates in the South African context after 1994. A brief overview of development provides the background of the development debate within South Africa.

The dominant notion of development has been viewed from the perspective of the North providing economic and technological aid to the South in order to develop the latter in line with the former. This was the case after the two world wars and the subsequent establishment of the Bretton Woods institutions. These institutions adopted a universal approach whose end was a greater Growth National Product through the provision of technical support, the sharing of technological information, loans and other forms of aid. This notion of development has been closely linked with exclusive economic development and formed the bases of the Modernisation and Dependency theories (Davids et al. 2009:7). 
Modernisation is the 'combination of mutual and social changes of a people which enable them to increase, cumulatively and permanently their total real production' (Bragg 1987:22):

The entire project was, however, based on several flawed assumptions: it supposed that what was good for the West would be good for the Third World also (in this respect, then, it was culturally insensitive) between the human subject and material object and believed that all the Third World stood in need of was technological expertise ... and it operated on the assumption that nothing in the rich North needed to change ... (Bosch 1991:433-434)

The more serious limitation of the modernisation theory was its proponents' ignorance of the extent of poverty and the root causes of underdevelopment among the developing countries (Bowers 2006:35). Some of the limitations of these theories also include the reduction of persons to commodities, persons being regulated by economic and social principles as well as technology, and that modern economics takes preference over human capital. This kind of development results in dependency, loss of fundamental societal structures, loss of creativity and imagination, the depleting of both renewable and non-renewable natural resources, and the dehumanising of persons through the false dichotomy of the private and the public.

Within the South African context, the NDP is by far the most comprehensive attempt by the South African government and the African National Congress to accelerate development among the South African society - particularly among the poor and marginalised. The predecessor of the NDP, the RDP of 1994, failed to address the inequalities enhanced by the separate development theory of the 1960s.

Although there was a relatively low increase of people living in poverty in the decade following the RDP, it was mainly because of the unprecedented increase of social grant expenditure (Burger, Louw \& Van der Watt 2010:61). The population growth, immigration from other African countries and high unemployment rate among the available employed people is the main contributing factors to the more than 16 million people who are living below the breadline. The state, faith based organisations and non-profit organisations are either implementing the modernisation development theories or charitable based development theories.

The RDP served as the election manifesto at the first democratic elections and are regarded as the single most successful contributor to the landslide victory by the African National Congress. 'It spelled out a vision for the total transformation of the South African society' (Swart et al 2010:17). The high unemployment rate, escalating population growth, ever widening gap between rich and poor, xenophobic and racist attacks, and diminishing popularity of the African National Congress is a far cry from the envisioned transformation of the South African society. These are some of the reasons for the establishment of a new development plan. I contend that the previous attempts towards development and transformation are the overemphasis on social policy towards social welfare and the lack of personal responsibility.

The church has played a very active role in the development debate in both apartheid and post-apartheid South Africa. The Dutch Reformed Church has had the most active and organised development programmes in South Africa and has been in partnership with the South African government in development and social welfare. Swart et al. (2010:289) summarises the policy and practice of the social welfare work of the Dutch Reformed Church in three development models as proposed by Kritzinger during the 20th century as 'structural holistic approach' up and till the 1950s; 'institutional approach' between 1950s and 1970s; and 'community-based approach' during the 1980s and 1990s. After a careful analysis of Kritzinger's proposed development models, Swart et al. (2010) asserts that:

the DRC's failure to adapt to a new model of effective socioeconomic involvement could be attributed especially to two factors: a theology of social charity that has shaped this church's social thinking and practice, and a stipulation that resulted in its charity services being in terms of its defined application policy quite exclusive. (p. 290)

There are correlations that can be drawn between development in the RDP and that of the DRC post-apartheid. Both approaches were appropriated on the basis of social welfare or charity. Development was providing immediate needs without taking in consideration the sustainability of such efforts. Both approaches neglected the role of personal responsibility for one's own development, including skills development and personal integrity.

On a more national scale and within the context of postapartheid South Africa, the church played an important role in the development debate through institutions such as the Ecumenical Foundation of Southern Africa. ${ }^{1}$ Since the establishment of the Reconstruction and Development Program, the church has continued to approach development from the mainstream development approach and in conjunction with the state. This approach is evident in the first three major ecumenical consultations organised by EFSA. At these consultations the focus was on critical engagement with the positions of the Bretton Woods institutions and the modernisation and dependency theories. The engagement with the approaches of these institutions was to critique the emphasis on economic development and to apply a more holistic approach to development as found in the Latin American liberation theology. The focus shifted from the liberal, free market economic policies and its outcomes of technological advancement and modernisation to a more social economic plan and human capital and capabilities. Social capital and human capabilities replaced technology and modernisation as the core components of development (Swart et al. 2010:16-17).

1.Some of the publications of EFSA include Koegelenberg (2001) and Louw \& Koegelenberg (2003). 
In the broader development debate, the approach by leading scholars such as David Korten (1990; 1995; 2006b:124) and Armatya Sen (1999a; 1999b; 2009) pioneered the shift from exclusively economic development to other forms of development that are more encompassing. Korten's writings from the 1990s emphasise development as people-centred. Within his four generation approach, generation two and three are people-centred. His writings of the 2000s move towards development as a global community replacing Empire style social arrangements. This shift finds expression in generation four. To this effect, Korten (1998) claims that for democracy to be restored:

we will need to remove the legal fiction of corporate personhood through which corporations have acquired more rights than persons and we will need to get corporations out of politics. (p. 398)

Sen, on the other hand, moves toward the capability of persons. Whilst the capabilities approach is closely related with the traditional notion of development, the capability approach does not make economic freedom the end itself. The traditional notion of development makes persons subjective to economics (Sen 1999a:1). Sen differs from the traditional or modernise notion of development by including the importance of ethics within development. He (Sen 1999b:6) asserts that control over properties or commodities do not guarantee development. He turns to Aristotle's words in the Nicomachean Ethics, 'wealth is evidently not the good we are seeking; for it is merely useful and for the sake of something else' (Ross 1980:7) to illustrate his critique of the modernisation theory. Sen (1999a) describes development as follows:

Expanding the freedoms we have reason to value not only makes our lives richer and more unfettered, but also allows us to be fuller social persons, exercising our own volitions and interacting with-and influencing-the world in which we live. (pp. 14-15)

Development in the South African context (the RDP and EFSA), from the perspectives of both the socio-political sphere and Christianity, focussed on the debates that were taking place in the international arena. There was an attempt to move away from the one way approach of development from the North to the South. Social welfare and dependency were two of the most criticised consequences of this notion of development. Within most mainline churches, during the early 1990s, the term development was fused with the liberation of people. Development and liberation became the two core concepts at the first three EFSA consultations between the early and mid1990s. The idea of liberation of people was part of the theological revolution in South America among the Roman Catholic theologians during the 1960s and 1970s. The discussion document SODEPAX - an initiative of the World Council of Churches and the Pontifical Commission on Justice and Peace - was an attempt to establish a theology of development and was largely influenced by liberation theology.

Development, as found in the RDP, EFSA, and that of Korten and Sen has progressed beyond the modernistic and dependency theories that treated development as a one way process of exclusive economic and technological advancement. Instead of production, human beings became the centre of development. Value goes beyond economic policies and technological innovations. An economic and market value was attached to everything that had being, including human, animal and ecological life. Opportunities and choices were presented to persons in which their being had worth, and both object and subject mattered.

The limitation of the above forms of development is situated in the position of personhood. Even when people became the focus of development, it was not to nurture the personhood of people into taking responsibility for development, but rather to add to the value of material trade. Persons became human capital in so far as they can be used for the advancement of economic trade and exchange of commodities.

\section{The NDP and responsibility}

To what extend has the NDP implemented responsibility for development? In ethics the difference is made between knowing and doing. In the visioning statement of the NDP there is a clear reference to taking responsibility for development:

We, the people of South Africa, have journeyed far since the long lines of our first democratic election on 27 April 1994, when we elected a government for all. We began to tell a story then. We have lived and renewed that story along the way. Now in 2030 we live in a country which we have made. We have created a home where everybody feels free yet bounded to others; where everyone embraces their full potential. We are proud to be a community that cares. We have received the mixed legacy of inequalities in opportunity and in where we have lived, but we have agreed to change our narrative of conquest, oppression, resistance. (National Planning Commission 2011:1)

This opening paragraph describes the projected future in the form of a vision statement. It describes the beginning of a narrative that starts with the first democratic election and moves to the possible future. The vision has three important parts. First, the people are active participants, made clear in the proclamation 'a country which we have made'; second, community 'where everybody feels free yet bounded to others' is a strong feature of the South African society; and third, persons can reach their 'full potential'.

These three parts indicates that the NDP builds on the RDP of 1994 and the associated debates within secular and religious spheres. People are not merely passive observers and receivers of welfare, but are rather active participants in the development. Persons became an important contributor to development. This was a shift in both the efforts of the state through policies such as the RDP and EFSA. Swart et al. (2010:17) points out that 'the EFSA development agenda could find important support and strategic momentum in the RDP, a document that echoed the people-centred development philosophy promoted at EFSA's first two conferences'. 
From a secular perspective, Korten's differentiation between The Empire Community story and The Earth Community story symbolises the participation of the people. The former reduces persons to subjects of an autocratic ruler. Persons are passive recipients of hand-outs. The Earth Community story replaces the cultural values of money and material abundance to life and spiritual fulfilment. Limited interpretation of rights as ownership is replaced by the health of families, policies that ensure all to have access to and benefit from the production, truth democracy, generosity and the responsibility to be good stewards. The political turning is about democracy of people instead of democracy of money, active citizenship instead of passive recipients, commitment to cooperation instead of selfish competition and social order by consensual responsibility and accountability instead of coercion (Korten 2006a; 2006b). To choose is crucial to the development of the current and future generations:

Our defining gift as humans is our power to choose, including our power to choose our collective future. It is a gift that comes with a corresponding moral responsibility to use that power in ways that work to the benefit of all people and the whole of life. (Korten 2009)

Sen also shifts towards the centrality of persons for development. The concept agency, as used by Sen, implies that the person is a doer in the development process. The person is thought of in collective terms and refers to the wellbeing of both the individual and the collective. As with the case of Korten, choice is a core element of development for Sen's development theory:

Sen gives us another glimpse into his notion of humanity when he makes the difference between human capital and human capabilities. Although the two is not mutually exclusive human capital enhances production while human capabilities concentrate on the abilities of people to lead the lives they value and enhance their choices. (Klaasen 2014:79)

The NDP and the notions of development, discussed in this article, acknowledge the value of personhood, but it does not make the acceptance of responsibility by the persons an intrinsic part of personhood and development. In the most explicit reference to responsibility, the NDP ascribes this task to leaders within 'government, business, labour and civil society' (National Planning Commission 2011:47). The Plan further refers to responsibility as accountability within various systems: 'Weak, poorly performing systems make it hard to attribute responsibility' (National Planning Commission 2011:50). This notion of responsibility, which is extrinsic to personhood and responsibility that is part of closed systems, has more to do with knowing than doing. Even where the NDP makes more explicit reference to 'own development' under the section, 'Citizens active in their own development' (National Planning Commission 2011:27), the role of the state, government, legislature, the judiciary and business takes preference over personhood as organs of development. The notion of own development, as it is presented in the plan, has the same weakness as Sen's attempt to shift development from exclusively economic development to agency.
Within Christian anthropology, ${ }^{2}$ the identity of a person is intrinsically connected to his or her calling. Genesis 1:27-28, the most common scripture used as a theological interpretation for what it means to be human, keeps person and calling as intricately related. De Gruchy (2003) claims:

It is important to recognise that in both creation accounts in Genesis, from which the affirmation of identity is traditionally drawn, the truth of being made in the image of God (1:17) or being filled with God's breath (2:7) is immediately coupled with the theme of vocation, the calling to be responsible actors in this world newly created by God (1:18; 2:5). (p. 24)

There is a clear indication that to be created in God's image goes beyond knowing what is right. It is also about doing what is right. The development debate is not only about institutions, projects or policies that provide opportunities and choices. It has to do with the calling that is connected with who one is. Identity is much more than knowing information - it is about doing with the information what is right. Lubardic (2011) captures Zizioulas' assertion that:

the ethical encompasses not only bringing oneself to an other in a morally acceptable form, but creating something good and beautiful in the world for one's other and one's ecclesial personhood to begin with. (pp. 578-579)

Personhood is an acting agent who is continuously formed and forming. Personhood is closer to the orthodox view of creation, namely that one is in a living process of formation and not a fixed finish product.

Another shortcoming of the NDP is the submerging of the individual into the community. Community forms a central part of the vision statement and demonstrates the interconnectedness of the South African society. This sense of community is entrenched in the word we that appears more than any other word in the vision statement as well as at the beginning of almost every sentence. The word is used in a typical African philosophical sense that puts the community over and against that of the individual.

Sen and Korten, and to a certain degree the RDP, go to the other extreme by using choice in a typical modern sense that makes the person a complete autonomous self. Choice is an important part of development. For Sen, development is nothing other than the expansion of choice. Korten views choice as a unique gift of humanity that is intrinsically part of what it means to be human. The person is viewed as independent of outside forces. The individual possesses the ability to make decisions through rationalisation. Choice constitutes what it means to be a person. The limitation of choice is that there is no guarantee that the individual will take responsibility, even if he or she is aware of possibilities or if information is made known to him or her.

The notion of community, as it is used in the NDP, causes the individual to be consumed as simply part of the collection

2.It is not intention to give an outline or analysis of Christian anthropology and the recent notions of evolutionary perspectives. For further interest on this notions of personhood, see Koopman (2003) 
of selves. The selves are connected merely by virtue of what is common to the group. In this case, he or she is denied personal choice unless it is for the common good of the group. Responsibility is limited to the collective and state organs. Policies, groups and communities become providers and agents of development.

Within African-Christian anthropology the individual is not placed above the community or the community above the individual. The either/or argument is well demonstrated in the contrasts between Gyekye's attempt to argue for reason as the single most significant determinant of personhood and Menkiti's notion of personhood as embedded in the supremacy of the community. For Gyekye community is not absolute and universal but rather what he refers to as 'moderate community'. ${ }^{3}$ 'Moderate or restricted communitarianism accommodates communal values as well as values of individuality, social commitments as well as responsibilities to oneself' (Gyekye 1997:76). On the other hand Menkiti follows Mbiti's notion (1975; 1990) of personhood as absolutely in community.

However, Matolino (2009) sets aside Gyekye's claim of 'moderate communitarianism'.

Gyekye attempts to show that moderate communitarianism is at least true for the Akans but immediately contradicts himself when he lays bare the essential beliefs of any form of communitarianism. (p. 164)

Both Gyekye and Menkiti agree that moral responsibility is central to personhood.

From an African-Christian perspective the creative tension between individualism and communitarianism is demonstrated in Tutu's Ubuntu community. Battle (1997) describes Tutu's community as interdependence between people in an environment of vulnerability in which true relationships foster the humanity of each other. Battle (1997) concludes:

[Tutu] stresses the Christian definition of relationship, as opposed to other social forms of communalism, to define Ubuntu. Influenced deeply by Anglican spirituality, Tutu is able to overcome African philosophy's tendency to go to the opposite extreme of discounting individuals for the sake of community. For him, being properly related in a theological Ubuntu does not denigrate individuality. Instead it builds an interdependent community (p. 42).

Such an interdependent community does not deny selfdetermination, but comes through deeper awareness than mere rationalisation, opportunities or choices. It comes through relationships with other persons in an open, trustworthy and honest environment. The self is not completely autonomous, but in its vulnerability penetrates the availability of choices and becomes an active forming and transforming agent.

3.For a discussion of Menkiti's idea of personhood in community against European philosophy's idea of the self as autonomous see Shutte (1993).

\section{Tutu (2004) claims:}

We are stewards of all of this ... The dominion we were given in Genesis 1:26 was so that we should rule as God's viceroys, doing it as God would-caring, gently, not harshly and exploitatively, with a deep reverence, for all is ultimately holy ground and we should figuratively take off our shoes for it all has the potential to be 'theophanic'-to reveal the divine. (pp. 28-29)

These kinds of creative relationships are made possible through transcendence of the self and the community. Relationship of an interdependent nature is as important for the self (self-concern, moral conscience, and ways of relating to their attitudes and actions) as it is for 'the other' (care, compassion, love and trust). This is not a reference to the other in a subordinate manner, but as a constructed other that is both a dependent and independent variable.

Community, which is characterised by interrelatedness, is demonstrated in the Christian notion of ecclesia. The ecclesia:

is possessed by a vision of God and the created order and engaged in a life-process. Unity is not to be equated with the denial of difference or the reduction of them all to one, but speaks of the mutual intercommunion and interpenetration of elements of difference. (Greenwood 1994:88)

Community is made up of vulnerable persons. The vulnerable person, according to LaCugna (in Medley 2002),

evokes mystery, compassion, reciprocity and obligation. It is as we look into another person's eyes and gaze upon the face of another person that we see with the 'eyes of the heart' and stand in openness before her and his ineffable and inexhaustible mystery. (p. 177)

\section{Conclusion}

The NDP is by far the most comprehensive effort by the South African government and the ruling political party to address underdevelopment post-apartheid. The plan builds on the critical engagements of religious and secular institutions with the narrow approaches of the modernistic and dependency theories on economic and technological development. The plan also takes seriously the weaknesses of the capability and people-centred approaches that is represented by Sen and Korten, respectively. Choice does not translate into development, because even if choices are given and opportunities made available, it does not guarantee taking responsibility for one's own development. The capability approach of Sen and sustainable development approach of Korten have points of contact with the RDP employed by the state to redress underdevelopment in South Africa. People are central for the development process. However, persons are still seen as a commodity.

The NDP does not consider the role of personhood for selfdevelopment. Personhood, from the perspective of Christian anthropology, implies responsibility for own development, because one's identity is locked up in your calling. Notwithstanding the role of the state and other political and social agencies, the person has an inherent responsibility for 
own development. Christian anthropology includes calling and interdependent relationships as part of reaching our potential image of God.

Personhood, as in Christian anthropology, is not restricted to the autonomous self, but finds expression in the creative relationship between the self and other selves. Unlike the dominant position, given to community in form of a collection of selves, Christian anthropology does not deny selfdetermination, but the self has her or his being in relationship with other selves. To take responsibility for development includes interaction with others as constructed other whose vulnerability evokes responsible action for development.

\section{Acknowledgements Competing interests}

The author declares that he has no financial or personal relationships which may have inappropriately influenced him in writing this article.

\section{References}

Battle, M., 1997, Reconciliation: The Ubuntu theology of Desmond Tutu, The Pilgrim Press, Ohio.

Bosch, J.B., 1991, Transforming mission: Paradigm shifts in theology of mission, Orbis Books, New York.

Bowers, N., 2006, Development as transformation: The local church in Lavender Hill as agent of change in a post-Carnegie 11 context, PhD dissertation, Stellenbosch University, Stellenbosch.

Burger, R., Louw, M. \& Van der Watt, C., 2010, in I. Swart (ed.), 'The challenge of poverty and social exclusion in post-apartheid South Africa-Considering the potential role of religious groups' Religion and social development in postapartheid South Africa, pp. 61-74, Sun Press, Stellenbosch.

Bragg, W.G., 1987, 'From development to transformation', in V. Samuel \& C. Sugden (eds.), The church in response to human need, pp. 20-51, Eerdmans, Grand Rapids, MI.

Davids, I., Theron, F. \& Maphunye, K. (eds.), 2009, Participatory development in South Africa: A development management perspective, 2nd edn., Van Schaik Publishers, Pretoria.

De Gruchy, S., 2003, 'Of agency, assets and appreciation: Seeking some commonalities between theology and development', Journal of theology for Southern Africa 117 20-39, November.

Greenwood, R., 1994, Transforming priesthood: A new theology of mission and ministry, SPCK, London.
Gyekye, K., 1997, Tradition and modernity: Philosophical reflections on the African experience, Oxford University Press, New York.

Klaasen, J., 2014, 'Towards an approach to development as mission: The category of personhood as addressed by Amartya Sen', Missionalia 42(1-2), 72-87.

Koegelenberg, R.A., 2001, 'Social development partnerships between religious communities and the state. Perspectives from the National Religious Association for Social Development (NRASD)', Journal of Theology for Southern Africa 110, 97-109.

Koopman, N., 2003, 'Trinitarian anthropology, Ubuntu and human rights', in K. Sporre \& H.R. Botman (eds.), Building a human rights culture: South African and Swedish perspectives, pp. 194-207, Stralins, Dalarna.

Korten, D.C., 1990, Getting to the 21st century: Voluntary action and the globa agenda, Kumarian, Connecticut.

Korten, D.C., 1995, When corporations rule the world, Kumarian Press, CT.

Korten, D.C., 2006a, 'From empire to earth community', Development 49(3), 76-81. https://doi.org/10.1057/palgrave.development.1100286

Korten, D.C., 2006b, The Great turning: From empire to earth community, Kumarian, Connecticut.

Korten, D.C., 2009, 'Life in a real-wealth economy', Development 52(3), 394-400. https://doi.org/10.1057/dev.2009.40

Louw, L. \& Koegelenberg, R.A., 2003, 'Building a New South Africa. The Building of a Caring, Democratic and Equitable Society through partnerships between the State and the National Religious Leader's Forum (NRLF). A perspective from the National Religious Association for Social Development (NRASD)', position paper prepared for the NRLF Meeting with President Thabo Mbeki, 29-30 April, viewed 11 July 2005, from http://sarpn.org.za/documents/d0000557/index.php

Lubardic, B., 2011, 'Orthodox theology of personhood: A critical overview', Expository Times 122(12), 573-581. https://doi.org/10.1177/0014524611415586

Matolino, B., 2009, 'Radicals versus moderates: A critique of Gyekye's moderate communitarianism', South African Journal of Philosophy 28(2), 160-170. https:// doi.org/10.4314/sajpem.v28i2.46674

Mbiti, J.S., 1975, Introduction to African religion, Heinemann Educational Books, London.

Mbiti, J.S., 1990, African religions and philosophy, Heinemann Educational Publishers, Oxford.

Medley, M.S., 2002, Imago Trinitatis: Toward a relational understanding of becoming human, University Press of America, Maryland.

National Planning Commission, 2011, National Development Plan: Our future-make it work, executive summary, viewed 8 August 2017, from http://www gov.za/sites/ www.gov.za/files/Executive $\% 20$ Summary-NDP\%202030\%20-\%200ur $\% 20$ future $\% 20-\% 20$ make $\% 20$ it $\% 20$ work

Ross, D., 1980, Nicomachean ethics, rev. edn., transl. D. Ross, Oxford University Press, Oxford.

Sen, A., 1999a, Commodities and capabilities, Oxford University Press, New Delhi.

Sen, A., 1999b, Development as freedom, Oxford University Press, Oxford.

Sen, A., 2009, The idea of justice, Penguin Books Ltd, London.

Shutte, A., 1993, Philosophy for Africa, University of Cape Town Press, Cape Town.

Swart, I., Rocher, H., Green, S. \& Erasmus, J. (eds.), 2010, Religion and socia development in post-apartheid South Africa, SUN Press, Stellenbosch.

Tutu, D., 2004, God has a dream: A vision of hope for our time, Random House, London. 